\title{
PERBEDAAN PENDAPATAN USAHATANI KARET (Hevea brasilineensis) KLON UNGGUL DAN KLON LOKAL DI KECAMATAN BIREM BAYEUN KABUPATEN ACEH TIMUR
}

\author{
Hanisah ${ }^{1} /$ Ulfatul Aulial $^{2}$ \\ ${ }^{1}$ Dosen Tetap Prodi Agribinis \\ ${ }^{2}$ Alumni Prodi Agribinisnis \\ Universitas Samudra
}

\section{RINGKASAN}

Tujuan penelitian untuk menganalisis perbedaan pendapatan usahatani karet klon unggul dan klon lokal di Kecamatan Birem Bayeun Kabupaten Aceh Timur.

Penelitian ini dilaksanakan di Kecamatan Birem Bayeun Kabupaten Aceh Timur. Penentuan lokasi penelitian dilakukan dengan sengaja (purposive), dengan pertimbangan bahwa di Kecamatan Birem Bayeun Kabupaten Aceh Timur terdapat usahatani karet bibit klon unggul dan klon lokal. Penelitian menggunakan metode survey. Objek penelitian ini adalah petani usahatani karet klon unggul dan klon lokal di Kecamatan Birem Bayeun Kabupaten Aceh Timur. Ruang lingkup penelitian ini hanya mengkaji pendapatan usahatani karet klon unggul dank klon lokal. Penelitian dilaksanakan pada bulan Februari sampai Maret 2017.

Hasil penelitian: Rata-rata pengunaan tenaga kerja usahatani karet klon lokal yaitu sebesar 211,06 HKP/UT/Tahun dan usahatani karet klon unggul yaitu sebesar 176,99 HKP/UT/ dengan rincian 115,02 HKP. Rata-rata biaya produksi usahatani karet klon lokal di Kecamatan Birem Bayeun yaitu sebesar Rp. 4.240.557,73,-- per UT/Tahun dan rata-rata biaya produksi usahatani karet klon unggul di Kecamatan Birem Bayeun yaitu sebesar Rp. 4.906.416,67- per UT/Tahun. Rata-rata produksi karet usaha usahatani klon lokal sebesar $5.933,33 \mathrm{Kg} / \mathrm{UT} / \mathrm{Tahun}$ dan rata-rata produksi usaha usahatani karet klon unggul yaitu sebesar $5.172 \mathrm{Kg} / \mathrm{UT} / \mathrm{Tahun}$. Rata-rata nilai produksi (pendapatan kotor) usahatani karet klon lokal di Kecamatan Birem Bayeun yaitu sebesar Rp. 38.783.020,83 per UT/Tahun dan rata-rata nilai produksi (pendapatan kotor) usahatani karet klon unggul di Kecamatan Birem Bayeun yaitu sebesar Rp. 43.966.250,- per UT/Tahun. Rata-rata pendapatan bersih usaha usahatani karet klon lokal di Kecamatan Birem Bayeun yaitu sebesar Rp. 34.542.463,11 per UT/Tahun dan Rp. 29.258.256,84 per Ha/Tahun. Sedangkan rata-rata pendapatan bersih usahatani karet klon unggul di Kecamatan Birem Bayeun yaitu sebesar Rp. 39.059.833,33- per UT/Tahun dan Rp. 33.543.318,45,- per Ha/Tahun. Kesimpulan penelitian yaitu: Ada perbedaan yang sangat nyata antara pendapatan bersih usahatani karet klon lokal dan klon unggul di Kecamatan Birem Bayeun.

Kata Kunci: Karet, Klon, Unggul, Lokal, Pendapatan

\section{PENDAHULUAN \\ Latar Belakang}

Tujuan dari pembangunan perkebunan adalah untuk meningkatkan produksi, memperbaiki mutu produksi, meningkatkan pendapatan, memperbesar nilai ekspor, mendukung industri, menciptakan dan memperluas kesempatan kerja, serta pemerataan pembangunan. Ada tiga asas yang menjadi acuan dalam pembangunan perkebunan yang mendasari kebijakan pembangunan dalam lingkungan ekonomi dan pembangunan nasional, yaitu mempertahankan dan meningkatkan sumbangan bidang perkebunan bagi pendapatan nasional; memperluas lapangan kerja dan AGRISAMUDRA, Jurnal Penelitian Vol. 4 No.2 Julii - Desember 2017 memelihara kekayaan serta kelestarian alam serta meningkatkan kesuburan sumberdaya alam.

Karet merupakan salah satu komoditi perkebunan penting, baik sebagai sumber pendapatan, kesempatan kerja dan devisa, pendorong pertumbuhan ekonomi sentra-sentra baru di wilayah sekitar perkebunan karet maupun pelestarian lingkungan dan sumberdaya hayati. Namun sebagai negara dengan luas areal terbesar dan produksi kedua terbesar dunia, Indonesia masih menghadapi beberapa kendala, yaitu rendahnya produktivitas, terutama karet rakyat yang merupakan mayoritas areal karet nasional dan ragam produk olahan yang masih 
terbatas, yang didominasi oleh karet remah (crumb rubber) (Siregar, 2008:46).

$$
\text { Dengan memperhatikan adanya }
$$

peningkatan permintaan dunia terhadap komoditi karet dimasa yang akan datang, maka upaya untuk meningkatkan pendapatan petani melalui perluasan tanaman karet dan peremajaaan kebun bisa merupakan langkah yang efektif untuk dilaksanakan. Untuk mendukung hal ini, perlu diadakan bantuan yang bisa memberikan modal bagi petani atau pekebun swasta untuk membiayai pembangunan kebun karet dan pemeliharaan tanaman secara intensif (Siregar, 2008:74).

Kondisi perkebunan karet saat ini menunjukkan bahwa karet dikelola oleh rakyat, perkebunan negara dan perkebunan swasta. Pertumbuhan karet rakyat masih positif walaupun lambat, sedangkan areal perkebunan negara dan swasta sama-sama menurun. Oleh karena itu, tumpuan pengembangan karet akan lebih banyak pada perkebunan rakyat. Namun luas areal kebun rakyat yang tua, rusak dan tidak produktif memerlukan peremajaan. Persoalannya adalah bahwa belum ada sumber dana yang tersedia untuk peremajaan dengan menggunakan klon unggul yang mempunyai produksi yang tinggi.

Propinsi Aceh memiliki potensi pengembangan tanaman karet yang cukup luas. Perkebunan karet rakyat di Propinsi Aceh tersebar hampir di sebagian besar kabupaten, salah satunya di Kabupaten Aceh Timur. Kecamatan Birem Bayeun merupakan salah satu sentra tanaman karet yang mempunyai potensi yang baik dimasa yang akan datang di Kabupaten Aceh Timur. Fenomena yang terjadi di Kecamatan Birem Bayeun perkebunan karet rakyat mengalami perkembangan yang cukup pesat. Tetapi masih banyak petani karet yang menggunakan bibit asalan yang berasal dari biji. Tanaman karet hasil perbanyakan dari biji biasanya mempunyai pertumbuhan lebih lambat, produksi rendah, tidak tahan serangan hama dan penyakit, matang panen lebih lambat dan pohon tidak seragam. perkebunan karet tersebut.

Kondisi perkebunan karet rakyat berbeda dengan perkebunan milik negara atau perkebunan besar swasta. Perbedaan tersebut terutama terlihat pada aspek skala usaha (luasan lahan pengelolaan usaha), teknologi budidaya dan manajemen, sehingga mengakibatkan tingkat produksi, produktivitas dan pendapatan usaha persatuan luas berbeda pula. Kegiatan pemuliaan karet di Indonesia melalui pusat penelitian tanaman karet telah banyak menghasilkan klon-klon karet unggul sebagai penghasil lateks dan penghasil kayu.

Potensi produktivitas karet klon-klon unggul yaitu antara 1,5 ton s/d 2,2 ton karet kering/hektar/pertahun. Produktivitas karet klonklon unggul tersebut sangat kontras jika dibandingkan dengan produktivitas karet di Kecamatan Birem Bayeun yang hanya mencapai 0,926 ton karet kering/hektar/tahun. Kenyataan di lapangan di Kecamatan Birem Bayeun dengan rata-rata produktivitas karet 0,926 ton/hektar/tahun menunjukkan bahwa tingkat penggunaan karet klon-klon unggul masih sangat rendah.

Pada kenyataan di Kecamatan Birem Bayeun petani karet menjalankan usahataninya dengan menggunakan bibit yang berasal dari klon unggul dan klon lokal. Klon unggul mempunyai kelebihan dibandingkan dengan klon lokal yaitu: produksi getah tinggi, tahan terhadap hama dan penyakit, respon terhadap pemupukan dan adaptasi tinggi terhadap perubahan iklim. Penggunaan dua jenis bibit klon yang berbeda besar kemungkinan akan menyebabkan produksi yang berbeda dan pada akhirnya menyebabkab pendapatan yang berbeda pula. Berdasarkan uraian latar belakang di atas maka penulis tertarik untuk menganalisis apakah ada perbedaan pendapatan usahatani karet yang menggunakan klon unggul dan klon lokal di Kecamatan Birem Bayeun Kabupaten Aceh Timur.

\section{Identifikasi Masalah}

"Apakah ada perbedaan pendapatan usahatani karet klon unggul dan klon lokal di Kecamatan Birem Bayeun Kabupaten Aceh Timur?"

\section{Tujuan penelitian}

"Untuk menganalisis perbedaan pendapatan usahatani karet klon unggul dan klon lokal di Kecamatan Birem Bayeun Kabupaten Aceh Timur" 


\section{Hipotesis Penelitian}

"Ada perbedaan yang nyata pendapatan usahatani karet klon unggul dan klon lokal di Kecamatan Birem Bayeun Kabupaten Aceh Timur"

\section{METODOLOGI PENELITIAN Lokasi, Objek, Ruang Lingkup dan Waktu Penelitian}

Penelitian ini dilaksanakan di Kecamatan Birem Bayeun Kabupaten Aceh Timur. Penentuan lokasi penelitian dilakukan dengan sengaja (purposive), dengan pertimbangan bahwa di Kecamatan Birem Bayeun Kabupaten Aceh Timur terdapat usahatani karet bibit klon unggul dan klon lokal. Penelitian menggunakan metode survey. Metode survey adalah penelitian yang diadakan untuk memperoleh fakta dari gejala-gejala yang ada dan mencari keterangan-keterangan secara faktual tentang institusi sosial, ekonomi atau politik dari suatau daerah (Nazir, 2005:56). Objek penelitian ini adalah petani usahatani karet klon unggul dan klon lokal di Kecamatan Birem Bayeun Kabupaten Aceh Timur. Ruang lingkup penelitian ini hanya mengkaji pendapatan usahatani karet klon unggul dank klon lokal.

Tabel III-1: Jumlah Populasi dan Jumlah Sampel Petani Karet di Kecamatan Birem Bayeun, 2016

\begin{tabular}{|l|l|c|c|c|c|}
\hline \multirow{2}{*}{ No } & \multirow{2}{*}{ Desa } & \multicolumn{2}{c|}{ Petani Karet Klon Unggul (orang) } & \multicolumn{2}{c|}{ Petani Karet Klon Lokal (orang) } \\
\cline { 3 - 6 } & Populasi & Sampel & Populasi & Sampel \\
\hline 1 & Blang Tualang & 56 & 6 & 64 & 6 \\
3 & Alue Teh & 45 & 4 & 58 & 6 \\
4 & Paya Bili Sa & 48 & 5 & 53 & 5 \\
\hline & Jambo Labu & 53 & 5 & 72 & 7 \\
\hline
\end{tabular}

Sumber: BPP Birem Bayeun, 2016

Dari tabel III-1 dapat dilihat bahwa jumlah keseluruhan petani karet klon unggul sebanyak 202 orang dengan petani sampel sebanyak 20 orang. Jumlah populasi petani karet klon lokal sebanyak 247 orang dengan petani sampel sebanyak 24 orang yang tersebar di 4 desa sampel.

Metode Analisis dan Pengujian Hipotesis

\section{Penentuan Sampel Penelitian}

Kecamatan Birem Bayeun terdiri dari 27 desa, dari 27 desa tersebut hanya 9 (Sembilan) desa yang terdapat usahatani karet rakyat. Dari sembilan desa tersebut dipilih 4 desa sebagai desa sampel. Penentuan desa sampel dilakukan secara purposive sampling (sengaja) dengan pertimbangan bahwa desa-desa sampel tersebut memiliki usahatani karet rakyat klon unggul dan klon lokal. Desa-desa tersebut adalah Desa Blang Tualang, Desa Alue Teh, Desa Paya Bili Sa dan Desa Jambo Labu.

Penentuan petani sampel dari masingmasing desa sampel ditentukan secara simple random sampling (sampel acak sederhana). Metode sampel acak sederhana adalah teknik penentuan sampel secara acak tanpa mengenal sampel dengan cara diundi dengan mengikutkan semua populasi yang ada untuk dipilih secara acak. Dalam penelitian ini besarn sampel yang digunakan adalah $10 \%$ dari jumlah populasi. Besaran sampel sebanyak $10 \%$ dari populasi dianggap layak untuk sebuah penelitian dengan populasi yang besar (Prasetyo dan Jannah, 2005:127). Untuk lebih jelas jumlah populasi dan sampel masing-masing desa sampel dapat dilihat pada tabel III-1 berikut: 
Dimana:

$\mathrm{X}_{1}$ dan $\mathrm{X}_{2}=$ Rata-rata pendapatan usahatani karet klon unggul dan klon lokal

$S_{1}^{2}$ dan $S_{2}^{2} \quad$ Rata-rata varian pendapatan bersih usahatani karet klon lokal dan klon lokal

$n_{1}$ dan $n_{2} \quad$ Jumlah petani sampel usahatani karet klon lokal dan klon lokal

Pengujian hipotesis sebagai berikut:

- Ha: yaitu ada perbedaan signifikan pendapatan usahatani karet klon unggul dan klon lokal di Kecamatan Birem Bayeun Kabupaten Aceh Timur

- Ho: yaitu tidak ada perbedaan signifikan pendapatan usahatani karet klon unggul dan klon lokal di Kecamatan Birem Bayeun Kabupaten Kriteria Uji :
- Terima Ha dan tolak Ho apabila t-hitung $>$ t-tabel, $\mathrm{db}=\mathrm{n}-1, \alpha=0.05$

- Tolak Ha dan terima Ho apabila t-hitung $<\mathrm{t}$-tabel, $\mathrm{db}=\mathrm{n}-1, \alpha=0.05$

Penggunaan alpha sebesar 5\% dalam uji statistik t-hitung sesuai dengan kebutuhan peneliti yang juga didasarkan pada pernyataan Usman, dkk (2008:85), bahwa dalam penelitian sosial, besarnya alpha (tingkat kesalahan) yang digunakan dapat bernilai $1 \%$ atau $5 \%$ atau tingkat keyakinan $95 \%$ dan $99 \%$.

\section{HASIL PENELITIAN DAN PEMBAHASAN Karakteristik Petani Sampel}

Karakteristik petani dalam penelitian ini meliputi luas lahan, umur, pendidikan, pengalaman dalam berusahatani karet dan besar tanggungan keluarga. Karakteristik petani usahatani karet klon lokal di Kecamatan Birem Bayeun dapat dilihat pada tabel V-1 berikut ini.

Tabel V-1. Rata-rata Karakteristik Petani Sampel Usahatani Karet Klon lokal di Kecamatan Birem Bayeun, 2017

\begin{tabular}{|c|l|l|l|l|l|}
\hline No & \multicolumn{1}{|c|}{ Desa } & $\begin{array}{r}\text { Umur } \\
\text { (Thn) }\end{array}$ & $\begin{array}{c}\text { Pendidikan } \\
\text { (Thn) }\end{array}$ & $\begin{array}{c}\text { Pengalaman } \\
\text { (Thn) }\end{array}$ & $\begin{array}{c}\text { Jumlah Tanggungan } \\
\text { Keluarga (Orang) }\end{array}$ \\
\hline 1 & Blang Tualang & 47,50 & 10,50 & 9,83 & 4,67 \\
2 & Alue Teh & 43,67 & 9,50 & 9,67 & 4,83 \\
3 & Paya Bili Sa & 45,60 & 9,60 & 10,20 & 5,40 \\
4 & Jambo Labu & 45.86 & 9,00 & 10,86 & 4,14 \\
\hline & Rata-rata & 45,67 & 9,63 & 10,17 & 5,00 \\
\hline
\end{tabular}

Sumber; Data primer diolah, 2017

Tabel V-1 di atas menjelaskan bahwa rata-rata luas lahan usahatani karet adalah 1,38 hektar, rata-rata umur adalah 45,67 Tahun merupakan umur yang produktif dalam mengusahakan usaha karet. Tingkat pendidikan rata-rata adalah 9,63 Tahun dengan rata-rata

Tabel V-2. Rata-rata Karakteristik Petani Sampel Usahatani Karet Klon Unggul di Kecamatan Birem Bayeun, 2017

\begin{tabular}{|l|l|l|l|l|l|}
\hline No & Desa & $\begin{array}{l}\text { Umur } \\
(\text { Thn })\end{array}$ & $\begin{array}{l}\text { Pendidikan } \\
(\text { Thn) }\end{array}$ & $\begin{array}{l}\text { Pengalaman } \\
(\text { Thn) }\end{array}$ & $\begin{array}{l}\text { Jumlah Tanggungan } \\
\text { Keluarga (Orang) }\end{array}$ \\
\hline 1 & Blang Tualang & 46,17 & 11,50 & 8,50 & 3,67 \\
2 & Alue Teh & 38,75 & 12,75 & 8,00 & 3,50 \\
3 & Paya Bili Sa & 42,20 & 11,40 & 10,00 & 3,40 \\
4 & Jambo Labu & 41,20 & 11,40 & 9,80 & 3,20 \\
\hline \multicolumn{2}{|l}{ Rata-rata } & 42,45 & 11,70 & 9,10 & 3,00 \\
\hline
\end{tabular}

pengalaman berusahatani 10,17 Tahun dan jumlah tanggungan keluarga rata-rata 5 orang. Karakteristik petani usahatani karet klon unggul di Kecamatan Birem Bayeun dapat dilihat pada tabel V-2 berikut ini. 
Sumber; Data primer diolah, 2017

Tabel V-1 di atas menjelaskan bahwa rata-rata luas lahan usahatani karet adalah 1,4 hektar, rata-rata umur adalah 42,45 Tahun merupakan umur yang produktif dalam mengusahakan usahatani karet. Tingkat pendidikan rata-rata adalah 11,70 Tahun dengan rata-rata pengalaman berusahatani 9,10 Tahun dan jumlah tanggungan keluarga rata-rata 3 orang. Karakteristik menunjukkan bahwa luas lahan usahatani karet kedua kelompok sampel petani relatif luas sehingga dapat menjadi sandaran hidup bagi petani. Pendidikan sampel petani usahatani karet klon lokal masih rendah, sehingga kemampuan untuk menerima teknologi baru tentang usahatani karet masih rendah. Sebaliknya sampel petani usahatani karet klon unggul lebih tinggi, sehingga kemampuan menerima teknologi baru usahatani karet lebih lebih tinggi. Semakin tinggi tingkat pendidikan petani, maka semakin kreatif petani dalam mengambil berbagai tindakan usaha, begitu juga Tabel V-3. Rata-Rata Penggunaan Tenaga Kerja Usahatani Karet Klon lokal di Kecamatan Birem Bayeun, 2017

\begin{tabular}{|l|l|l|l|l|l|l|l|}
\hline \multirow{2}{*}{ No } & & \multicolumn{2}{|c|}{ TKDK $($ HKP $)$} & \multicolumn{2}{c|}{ TKLK (HKP) } & \multicolumn{2}{c|}{ Total (HKP) } \\
\cline { 3 - 8 } & \multicolumn{1}{|c|}{ Desa } & PerUT & PerHa & PerUT & PerHa & PerUT & PerHa \\
\hline 1 & Blang Tualang & 149,22 & 100,83 & 85,40 & 57,70 & 234,62 & 158,53 \\
3 & Alue Teh & 100,83 & 100,60 & 57,70 & 70,20 & 206,76 & 170,80 \\
4 & Paya Bili Sa & 100,60 & 120,72 & 70,20 & 83,04 & 203,18 & 203,76 \\
\hline & Jambo Labu & 120,72 & 130,78 & 83,04 & 90,46 & 200,17 & 221,24 \\
\hline
\end{tabular}

Sumber; Data primer diolah, 2017

Tabel V-3 menjelaskan rata-rata penggunaan tenaga kerja usahatani karet klon lokal yaitu sebesar 211,06 HKP/UT/Tahun dan 179,62 $\mathrm{HKP} / \mathrm{Ha}$ /tahun. Tenaga kerja dalam keluarga

Tabel V-4. Rata-Rata Penggunaan Tenaga Kerja Usahatani Karet Klon Unggul di Kecamatan Birem Bayeun, 2017

\begin{tabular}{|l|l|l|l|l|l|l|l|}
\hline \multirow{2}{*}{ No } & \multirow{2}{*}{} & \multicolumn{2}{l|}{ TKDK $($ HKP) } & \multicolumn{2}{l|}{ TKLK $($ HKP $)$} & \multicolumn{2}{l|}{ Total (HKP) } \\
\cline { 3 - 8 } & Desa & PerUT & PerHa & PerUT & PerHa & PerUT & PerHa \\
\hline 1 & Blang Tualang & 120,72 & 100,60 & 65,04 & 54,20 & 185,76 & 154,80 \\
2 & Alue Teh & 103,12 & 100,11 & 55,56 & 53,94 & 143,98 & 139,78 \\
3 & Paya Bili Sa & 109,99 & 93,21 & 63,96 & 54,20 & 169,25 & 143,43 \\
4 & Jambo Labu & 122,73 & 100,60 & 66,12 & 54,20 & 188,86 & 154,80 \\
\hline & Rata-rata & 115,02 & 104,56 & 63,14 & 57,40 & 174,05 & 158,23 \\
\hline
\end{tabular}

Sumber; Data primer diolah, 2017 sebaliknya semakin rendah tingkat pendidikan petani maka semakin lambat dalam mengambil berbagai keputusan strategis usahatani sehingga berpengaruh terhadap keberhasilan usaha. Pengalaman dari kedua kelompok sampel dalam berusaha usahatani karet cukup lama sehingga kegagalan dan resiko yang akan dihadapi akan semakin kecil dan dapat dikatakan cukup mahir dalam menjalankan usahatani karet padi sawah. Jumlah tanggungan keluarga rata-rata 3 dan 5 orang merupakan tanggungan yang relatif kecil sehingga petani bisa lebih fokus dan mampu membiayai usaha usahatani karet dengan baik.

\section{Penggunaan Tenaga Kerja}

Dalam menghitung besarnya pencurahan tenaga kerja yang diserap untuk setiap fase kegiatan, seluruhnya dikonversikan ke dalam Hari Kerja Pria (HKP). Rata-rata penggunaan tenaga kerja usahatani karet klon lokal dapat dilihat pada tabel V-4 berikut. sebesar 118,21 HKP/UT/Tahun dan 100,6 $\mathrm{HKP} / \mathrm{Ha} / \mathrm{Tahun}$. Tenaga kerja luar keluarga sebesar 92,85 HKP/UT/Tahun dan 79,02 $\mathrm{HKP} / \mathrm{Ha} / \mathrm{Tahun}$. 
Tabel V-4 di atas dapat dilihat bahwa rata-rata pengunaan tenaga kerja usahatani karet klon unggul yaitu sebesar 174.05 HKP/UT/Tahun dan 158,23 HKP/Ha/Tahun. Tenaga kerja dalam keluarga rata-rata sebesar 115,02 HKP/UT/Tahun dan 104,56 HKP/Ha/Tahun. Tenaga kerja luar keluarga rata-rata sebesar 63,14 HKP/UT/Tahun dan 57,4 HKP/Ha/Tahun.

Mengacu pada Tabel V-3 dan IV-4 menunjukkan terdapat perbedaan penggunaan tenaga kerja diantara usahatani karet klon lokal dan klon unggul. Perbedaan penggunaan tenaga kerja disebabkan karena pada usahatani karet klon lokal hanya sedikit memerlukan tenaga kerja khususnya pada pemeliharaan dan pemupukan, sedangkan pada usahatani karet klon unggul praktis banyak tenaga kerja yang dibutuhkan karena setiap tahapan usahatani dilaksanakan berdasarkan perencanaan yang mengikuti prosedur usahatani karet yang standar.

\section{Biaya Produksi}

Pengertian biaya produksi dalam penelitian ini adalah semua biaya yang diperlukan untuk memperlancar kegiatan usahatani karet. Biaya tetap (Fixed Cost) dalam penelitian ini adalah sewa lahan, biaya penyusutan dan pajak bumi dan bangunan (PBB). Sedangkan biaya variabel adalah biaya yang dikeluarkan untuk membeli benih, pakan, pupuk, pestisida dan membayar upah tenaga kerja.

Rata-rata penggunaan biaya produksi usahatani karet klon lokal di Kecamatan Birem Bayeun dapat dilihat pada tabel V-5 berikut ini:

Tabel V-5. Rata-Rata Biaya Produksi Usahatani Karet Klon lokal di Kecamatan Birem Bayeun, 2017

\begin{tabular}{|l|l|l|l|l|l|l|l|}
\hline \multirow{2}{*}{ No } & & \multicolumn{2}{l|}{ Biaya Tetap (Rp/MT) } & \multicolumn{2}{l|}{ Biaya Variabel (Rp/MT) } & \multicolumn{2}{l|}{ Total Biaya (Rp/MT) } \\
\cline { 3 - 8 } & Desa & PerHa & PerUT & PerHa & PerUT & PerHa \\
\hline \multirow{2}{*}{2} & Bl Tualang & $1.997 .694,44$ & 1.349 .793 .54 & $3.300 .416,67$ & $2.230 .011,26$ & $5.298 .111,11$ & $3.579 .804,80$ \\
3 & Alue Teh & $1.541 .703,13$ & 1.284 .752 .60 & $2.670 .000,00$ & $2.225 .000,00$ & $4.211 .703,13$ & $3.509 .752,60$ \\
4 & Paya Bili Sa & $1.564 .366,67$ & 1.448 .487 .65 & $2.403 .000,00$ & $2.225 .000,00$ & $3.967 .366,67$ & $3.673 .487,65$ \\
\hline & Jambo Labu & $1.424 .309,52$ & 1.483 .655 .75 & $2.129 .642,86$ & $2.218 .377,98$ & $3.553 .952,38$ & $3.702 .033,73$ \\
\hline
\end{tabular}

Sumber; Data primer diolah, 2017

Tabel V-5 di atas dapat dilihat rata-rata biaya produksi usahatani karet klon lokal di Kecamatan Birem Bayeun yaitu sebesar Rp. 4.240.557,73,-/UT/Tahun dan 3.593.692,99/Ha/Tahun. Biaya tetap rata-rata sebesar Rp. 1.626.182,73/UT/Tahun dan Rp. 1.378.120,95/Ha/Tahun. Biaya variabel rata-rata sebesar Rp. 2.614.375/UT/Tahun dan Rp. 2.215.572,03/Ha/Tahun.

Rata-rata penggunaan biaya produksi pada usahatani karet klon unggul di Kecamatan Birem Bayeun dapat dilihat pada tabel V-6 berikut ini :

Tabel V-6. Rata-Rata Biaya Produksi Usahatani Karet Klon Unggul di Kecamatan Birem Bayeun, 2017

\begin{tabular}{|l|l|l|l|l|l|l|l|}
\hline \multirow{2}{*}{ No } & & Desa & \multicolumn{2}{l|}{ Biaya Tetap (Rp/MT) } & \multicolumn{2}{l|}{ Biaya Variabel (Rp/MT) } & \multicolumn{2}{l|}{ Total Biaya (Rp/MT) } \\
\cline { 3 - 8 } 1 & PerUT & PerHa & PerUT & PerHa & \multicolumn{2}{l|}{ PerUT } & PerHa \\
\hline 1 & BlTualang & $1.643 .611,11$ & $1.369 .675,93$ & $3.420 .000,00$ & $2.850 .000,00$ & $5.063 .611,11$ & $4.219 .675,93$ \\
2 & Alue Teh & $1.430 .708,33$ & $1.389 .037,22$ & $2.921 .250,00$ & $2.836 .165,05$ & $4.351 .958,33$ & $4.225 .202,27$ \\
3 & Paya Bili Sa & $1.584 .400,00$ & $1.342 .711,86$ & $3.363 .000,00$ & $2.850 .000,00$ & $4.947 .400,00$ & $4.192 .711,86$ \\
4 & Jambo Labu & $1.643 .366,67$ & $1.347 .021,86$ & $3.477 .000,00$ & $2.850 .000,00$ & $5.120 .366,67$ & $4.197 .021,86$ \\
\hline & Rata-rata & $1.586 .166,67$ & $1.355 .698,01$ & $3.320 .250,00$ & $2.837 .820,51$ & $4.906 .416,67$ & $4.193 .518,52$ \\
\hline
\end{tabular}

Sumber; Data primer diolah, 2017

Tabel V-6 di atas dapat dilihat bahwa rata-rata biaya produksi usahatani karet klon unggul di AGRISAMUDRA, Jurnal Penelitian Vol. 4 No.2 Julii - Desember 2017
Kecamatan Birem Bayeun yaitu sebesar Rp. 4.906.416,67/UT/Tahun dan Rp.4.193.518,52/ 
$\mathrm{Ha} / \mathrm{Tahun}$. Biaya tetap rata-rata sebesar $\mathrm{Rp}$. 1.586.166,67/UT/Tahun dan Rp. 1.355.698,01/ $\mathrm{Ha} / \mathrm{Tahun}$. Biaya variabel rata-rata sebesar Rp. 3.320.250,/UT/Tahun dan Rp. 2.837.820,51/ $\mathrm{Ha} / \mathrm{Tahun}$.

Dengan mengacu pada Tabel V-5 dan

Tabel V-6 maka terdapat perbedaan rata-rata biaya produksi usahatani karet klon lokal dan klon unggul. Perbedaan biaya produksi tersebut disebabkan pada usahatani karet klon unggul lebih banyak menggunakan pupuk perhektarnya sehingga biaya membeli pupuk lebih besar, selanjutnya biaya tenaga kerja juga lebih besar, karena klon unggul pupuk akan diberikan teratur setiap tahun sehingga biaya pupuk akan menjadi lebih besar. Tetapi biaya yang lebih besar akan tertutupi dangan produksi yang tinggi dimana jumlah getah yang dipanen lebih banyak.

\section{Produksi Karet}

Produksi adalah hasil produksi getah (lateks) yang diperoleh petani dari usahatani karet dalam bentuk karet lum (mangkuk). Produksi karet biasanya dapat dipanen pada setiap minggu. Rata-rata produksi usahatani karet klon lokal di Kecamatan Birem Bayeun dapat dilihat pada tabel V-7 berikut ini.

Tabel V-7. Rata-Rata Produksi Pada Usahatani Karet Klon lokal di Kecamatan Birem Bayeun, 2017

\begin{tabular}{|l|l|c|c|}
\hline \multirow{2}{*}{ No } & \multicolumn{1}{|c|}{ Desa } & \multicolumn{2}{|c|}{ Produksi (Kg/Thn) } \\
\cline { 3 - 4 } & \multicolumn{1}{|c|}{ PerUT } & PerHa \\
\hline 1 & Blang Tualang & $5.933,33$ & $4.009,01$ \\
3 & Alue Teh & $4.440,00$ & $3.700,00$ \\
4 & Paya Bili Sa & $4.428,00$ & $4.100,00$ \\
\hline & Jambo Labu & $3.589,29$ & $3.738,84$ \\
\hline
\end{tabular}

Sumber; Data primer diolah, 2017

Tabel V-7 di atas dapat dilihat bahwa rata-rata produksi karet usaha usahatani klon lokal

sebesar 5.933,33 $\mathrm{Kg} / \mathrm{UT} / \mathrm{Tahun}$ dan $3.866,70$ $\mathrm{Kg} / \mathrm{Ha} / \mathrm{Tahun}$.

Tabel IV-8. Rata-Rata Produksi Pada Usahatani Karet Klon Unggul di Kecamatan Birem Bayeun, 2017

\begin{tabular}{|l|l|c|c|}
\hline \multirow{2}{*}{ No } & \multicolumn{1}{|c|}{ Desa } & \multicolumn{2}{|c|}{ Produksi (Kg/Thn) } \\
\cline { 3 - 4 } 1 & Blang Tualang & $5 . .400,00$ & PerHa \\
2 & Alue Teh & $4.715,00$ & $4.500,00$ \\
3 & Paya Bili Sa & $5.192,00$ & $4.577,67$ \\
4 & Jambo Labu & $5.246,00$ & $4.400,00$ \\
\hline & Rata-rata & $5.172,50$ & $4.300,00$ \\
\hline
\end{tabular}

Sumber; Data primer diolah, 2017

Tabel V-8 di atas dapat dilihat bahwa rata-rata produksi usaha usahatani karet klon unggul yaitu sebesar $5.172 \mathrm{Kg} / \mathrm{UT} / \mathrm{Tahun}$ dan 4.420,94 $\mathrm{Kg} / \mathrm{Ha} / \mathrm{Tahun}$.

Dengan mengacu pada Tabel V-7 dan Tabel V-8 maka terdapat perbedaan rata-rata produksi usaha usahatani karet klon lokal dan klon unggul sebesar 609,79 $\mathrm{Kg} / \mathrm{UT} / \mathrm{Thn}$ di
Kecamatan Birem Bayeun. Selisih produksi sebesar 609,79 $\mathrm{Kg} / \mathrm{Ha} /$ Tahun adalah sebuah perbedaan yang besar sehingga petani usahatani karet klon unggul memperoleh pendapatan jauh lebih besar dibandingkan dengan petani karet klon lokal dikarenakan perbedaan produksi yang cukup besar. 


\section{Nilai Produksi (Pendapatan Kotor) Usaha Usahatani Karet}

Nilai produksi (pendapatan kotor) adalah total perkalian produksi dan harga produksi yang diterima petani karet. Nilai produksi sangat ditentukan oleh harga yang berlaku saat petani menjual hasil produksinya.
Pada saat penelitian ini dilakukan harga karet yang diterima petani karet di Kecamatan Birem Bayeun adalah Rp. 8.500,- per kilogram. Ratarata nilai produksi usahatani karet klon lokal di Kecamatan Birem Bayeun dapat dilihat pada tabel V-9 berikut ini.

Tabel V-9. Rata-Rata Nilai Produksi Pada Usahatani Karet Klon lokal di Kecamatan Birem Bayeun, 2017

\begin{tabular}{|l|l|l|l|}
\hline & & \multicolumn{2}{|l|}{ Nilai Produksi (Rp/Thn) } \\
\cline { 3 - 4 } No & Desa & PerUT & PerHa \\
\hline 1 & Blang Tualang & $50.433 .333,33$ & $34.076 .576,58$ \\
2 & Alue Teh & $37.740 .000,00$ & $31.450 .000,00$ \\
3 & Paya Bili Sa & $37.638 .000,00$ & $34.850 .000,00$ \\
4 & Jambo Labu & $30.508 .928,57$ & $31.780 .133,93$ \\
\hline & Rata-rata & $38.783 .020,83$ & $32.866 .966,81$ \\
\hline
\end{tabular}

Sumber; Data primer diolah, 2017

Tabel V-9 di atas dapat dilihat bahwa rata-rata nilai produksi usahatani karet klon lokal di Kecamatan Birem Bayeun yaitu sebesar Rp. 38.783.020,83/UT/Tahun dan Rp.32.866.966

Rata-rata nilai produks usahatani karet klon unggul di Kecamatan Birem Bayeun dapat dilihat pada tabel V-10 berikut ini.

, $81 / \mathrm{Ha} / \mathrm{Tahun}$.

Tabel V-10. Rata-Rata Nilai Produksi Pada Usahatani Karet Klon Unggul di Kecamatan Birem Bayeun, 2017

\begin{tabular}{|l|l|l|l|}
\hline & & \multicolumn{2}{|l|}{ Nilai Produksi (Rp/Thn) } \\
\cline { 3 - 4 } No & Desa & PerUT & PerHa \\
\hline 1 & Blang Tualang & $45.900 .000,00$ & $38.250 .000,00$ \\
2 & Alue The & $40.077 .500,00$ & $38.910 .194,17$ \\
3 & Paya Bili Sa & $44.132 .000,00$ & $37.400 .000,00$ \\
4 & Jambo Labu & $44.591 .000,00$ & $36.550 .000,00$ \\
\hline & Rata-rata & $43.966 .250,00$ & $37.577 .991,45$ \\
\hline
\end{tabular}

Sumber; Data primer diolah, 2017

Tabel IV-11 di atas dapat dilihat bahwa rata-rata nilai produksi (pendapatan kotor) usahatani karet klon unggul di Kecamatan Birem Bayeun yaitu sebesar Rp. 43.966.250/UT/Tahun dan Rp. 37.577.991,45/Ha/Tahun.

Mengacu pada Tabel V-9 dan V-10, terdapat perbedaan rata-rata nilai produksi usahatani karet klon lokal dan klon unggul sebesar Rp. 5.183.230, per UT/Tahun. Perbedaan pendapatan kotor antara usaha usahatani karet klon lokal dan klon unggul

sebesar Rp. 5.183.230,- merupakan perbedaan yang besar yang disebabkan perbedaan produksi perhektar.

\section{Pendapatan Bersih Usahatani Karet}

Pendapatan bersih yaitu selisih antara nilai produksi dengan total biaya produksi. Ratarata pendapatan bersih usaha usahatani karet klon lokal di Kecamatan Birem Bayeun dapat dilihat pada tabel V-11 berikut ini. 
Tabel V-11. Rata-Rata Pendapatan Bersih Usaha Usahatani Karet Klon lokal di Kecamatan Birem Bayeun, 2016

\begin{tabular}{|l|l|l|l|}
\hline No & Desa & Pendapatan Bersih $(\mathrm{Rp} / \mathrm{UT} / \mathrm{Thn})$ & Pendapatan Bersih $(\mathrm{Rp} / \mathrm{Ha} / \mathrm{Thn})$ \\
\hline 1 & Blang Tualang & $45.135 .222,22$ & $30.496 .771,77$ \\
2 & Alue Teh & $33.528 .296,88$ & $27.940 .247,40$ \\
3 & Paya Bili Sa & $33.670 .633,33$ & $31.176 .512,35$ \\
4 & Jambo Labu & $26.954 .976,19$ & $28.078 .100,20$ \\
\hline & Rata-rata & $34.542 .463,11$ & $29.273 .273,82$ \\
\hline
\end{tabular}

Sumber; Data primer diolah, 2017

Tabel V-11 di atas dapat dilihat bahwa rata-rata pendapatan bersih usaha usahatani karet klon lokal di Kecamatan Birem Bayeun yaitu sebesar Rp. 34.542.463,11 per UT/Tahun dan Rp. 29.273.273,82 per Ha/Tahun.
Rata-rata pendapatan bersih usahatani karet klon unggul di Kecamatan Birem Bayeun dapat dilihat pada tabel V-12 berikut.

Tabel V-12. Rata-Rata Pendapatan Bersih Usahatani Karet Klon Unggul di Kecamatan Birem Bayeun, 2017

\begin{tabular}{|l|l|l|l|}
\hline No & Desa & Pendapatan Bersih (Rp/UT/Thn) & Pendapatan Bersih (Rp/Ha/Thn) \\
\hline 1 & Blang Tualang & $40.836 .388,89$ & $34.030 .324,07$ \\
2 & Alue Teh & $35.725 .541,67$ & $34.684 .991,91$ \\
3 & Paya Bili Sa & $39.184 .600,00$ & $33.207 .288,14$ \\
4 & Jambo Labu & $39.470 .633,33$ & $32.352 .978,14$ \\
\hline & Rata-rata & $39.059 .833,33$ & $33.384 .472,93$ \\
\hline
\end{tabular}

Sumber; Data primer diolah, 2017

Tabel V-12 di atas dapat dilihat bahwa rata-rata pendapatan bersih usahatani karet klon unggul di Kecamatan Birem Bayeun yaitu sebesar Rp. 39.059.833,33- per UT/Tahun dan Rp. 33.338.472,93,- per Ha/Tahun.

Dengan mengacu pada Tabel V-11 dan Tabel V-12 maka terdapat perbedaan rata-rata pendapatan bersih usaha usahatani karet klon lokal dan klon unggul di Kecamatan Birem Bayeun sebesar Rp. 4.285.061,61 per Ha/Tahun.

Analisis Perbedaan Pendapatan Usahatani Karet Klon lokal dan Klon Unggul di Kecamatan Birem Bayeun.

Berdasarkan hasil penelitian diperoleh data ada perbedaan pendapatan bersih antara usahatani karet klon lokal dan klon unggul di Kecamatan Birem Bayeun, dimana pendapatan bersih usahatani karet klon unggul lebih tinggi dibandingkan dengan pendapatan bersih usahatani karet klon lokal. Untuk lebih meyakinkan apakah perbedaan tersebut nyata atau tidak nyata secara statistik, maka dilakukan pengujian statistik uji "t".

Dari hasil perhitungan tersebut diperoleh $t_{\text {cari }}=7,116$ sedangkan $t_{\text {tabel }}$ pada tingkat keyakinan 95\% $(\alpha=0.05)$ sebesar 1,67 dan pada tingkat keyakinan 99\% $(\alpha=0.01)$ sebesar 2,39. Ini berarti $t_{\text {cari }}>t_{\text {tabel }}$ baik pada tingkat keyakinan 95\% maupun 99\%. Dengan demikian dapat disimpulkan terima $\mathrm{Ha}$ dan tolak Ho. Artinya ada perbedaan yang sangat nyata antara pendapatan bersih usahatani karet klon lokal dan klon unggul di Kecamatan Birem Bayeun.

\section{KESIMPULAN DAN SARAN Kesimpulan}

1. Rata-rata pendapatan bersih usaha usahatani karet klon lokal di Kecamatan Birem Bayeun yaitu sebesar Rp. 34.542.463,11 per UT/Tahun dan Rp. 29.258.256,84 per Ha/Tahun. Sedangkan rata-rata pendapatan bersih usahatani karet klon unggul di 
Kecamatan Birem Bayeun yaitu sebesar Rp. 39.059.833,33- per UT/Tahun dan Rp. 33.543.318,45,- per Ha/Tahun

2. Dari hasil perhitungan tersebut diperoleh $t_{\text {cari }}=-31,560$ sedangkan $t$ tabel pada tingkat keyakinan 95\% $(\alpha=0.05)$ sebesar 1,67 dan pada tingkat keyakinan $99 \%(\alpha=0.01)$ sebesar 2,39 . Ini berarti $t_{\text {cari }}>t_{\text {tabel }}$ baik pada tingkat keyakinan $95 \%$ maupun 99\%. Dengan demikian dapat disimpulkan terima $\mathrm{Ha}$ dan tolak Ho. Artinya ada perbedaan yang sangat nyata antara pendapatan bersih usahatani karet klon lokal dan klon unggul di Kecamatan Birem Bayeun.

\section{Saran}

1. Perlu kajian yang mendalam mengenai faktor-faktor penyebab masih adanya usahatani karet dengan klon lokal, dimana berdasarkan hasil penelitian ini pendapatannya jauh lebih rendah dibandingkan yang menggunakan klon unggul.

2. Jika diketahaui faktor-faktor penyebab petani karet masih menggunakan klon lokal maka perlu dipikirkan alternatif penyelesaian masalah yang pada akhirnya ketika petani beralih menggunakan klon unggul karena produksinya lebih tinggi.

3. Disarankan kepada petani karet klon lokal yang sudah memasuki akhir umur produktif untuk beralih menggunakan karet klon unggul yang dapat diperoleh melalui penangkar yang resmi karena sudah terbukti mendapatkan pendapatan yang lebih tinggi.

\section{DAFTAR PUSTAKA}

Anwar Chairil. 2001. Teknologi Budidaya Karet. Pusat Penelitian Karet Medan.

[BPS] Badan Pusat Statistik Aceh. 2016. Dinas Perkebunan. Tentang Areal dan produksi Perkebunan.

Badan Penyuluhan Pertanian Kecamatan Birem Bayeun. 2016. Tentang Luas Areal
Tanaman Karet di Kecamatan Birem Bayeun

Balai Penelitian Sembawa, 2009. Perakitan Sistem Eksploitasi Tanaman Karet dengan Siklus Ekonomi Dipersingkat, Balai Penelitian Sembawa, NTB

Dian Mardias. 2012. Jurnal:"Pola Pengembangan Perkebunan Karet Rakyat dalam Rangka Upaya Peningkatan Produksi dan Pendapatan Petani di Kabupaten Kampar. FE UNRI. Pekan Baru

Daniel, M. 2001. Pengantar Ekonomi Pertanian. Bumi Aksara, Jakarta.

Hermanto. 2001. Ilmu Usahatani. Penenbar Swadaya: Jakarta.

Mubyarto, 2001, Pengantar Ekonomi Pertanian, LP3ES, Jakarta

Nazaruddin dan F.B. Paimin., 1998. Karet. Penebar Swadaya. Jakarta.

Nazir, Moh. 2005. Metode Penelitian. Cetakan Pertama. Penerbit Ghalia Indonesia. Jakarta.

Prasetyo, Bambang dan Lina M.Jannah. 2005. Metode Penelitian Kualitatif. Jakarta. PT Raja Grafindo Persada

Prawirokusumo, S. 2005. Ilmu Usaha Tani, BPIE Yogyakarta.

Rahim dan Diah Retno, 2007, Ekonomika Pertanian, Penebar Swadaya, Jakarta

Siregar Tumpal HS, 2008. Budidaya Tanaman Karet. BP Karet Sei Putih, Sumatera Utara

Soekartawi et al. 2002. Ilmu Usahatani dan Peneitian untuk Pengembangan Petani Kecil. Universitas Indonesia Press, Jakarta.

Sugiyono, 2007. Metode Penelitian Bisnis dan Aplikasi. Alfabeta, Bandung.

Tim Penulis Penebar Swadaya. 2008. Budidaya Tanaman Karet. Penebar Swadaya. Jakarta

Umar Husein, 2002. Pengantar Teori Penelitian. PPB FIP UPI, Bandung.

Usman. H dan Akbar. P.S. 2008. Pengantar Statistik. Edisi Kedua. Bumi Aksara. Jakarta. 